Review

\title{
Azithromycin: A new concept in adjuvant treatment of periodontitis
}

\author{
Francisco Wilker Mustafa Gomes Muniz ${ }^{a, *}$, Camila Carvalho de Oliveira ${ }^{b}$, Rosimary de \\ Sousa Carvalho ${ }^{c}$, Maria Mônica Studart Mendes Moreira ${ }^{\mathrm{d}}$, Maria Elisabete Amaral de \\ Moraes ${ }^{\mathrm{e}}$, Ricardo Souza Martins ${ }^{\mathrm{f}}$ \\ a School of Dentistry, Faculty of Pharmacy, Denstistry and Nursing, Federal University of Ceará, 570, Vereador Pedro Paulo Street, Fortaleza, Ceará 60430-355, Brazil \\ ${ }^{\mathrm{b}}$ School of Dentistry, Faculty of Pharmacy, Denstistry and Nursing, Federal University, 61, Luis Carlos Felix Street, Fortaleza, Ceará, Brazil \\ c Discipline of Periodontology, School of Pharmacy, Dentistry and Nursing, Federal University of Ceará, 100, da Paz Street, Fortaleza, Ceará, Brazil \\ d Discipline of Periodontology, School of Pharmacy, Dentistry and Nursing, Federal University of Ceará, Monsenhor Furtado Street, Fortaleza, Ceará, Brazil \\ e Faculty of Medicine, Federal University of Ceará, 1127, Coronel Nunes Melo, Fortaleza, Ceará, Brazil \\ ${ }^{\mathrm{f}}$ Discipline of Periodontology, School of Pharmacy, Dentistry and Nursing, Federal University of Ceará, 555, Waldemar de Alcântara Street, Fortaleza, Ceará, Brazil
}

\section{A R T I C L E I N F O}

\section{Article history:}

Received 16 July 2012

Received in revised form

31 January 2013

Accepted 13 February 2013

Available online 13 March 2013

Keywords:

Azithromycin

Treatment

Periodontitis

\begin{abstract}
A B S T R A C T
In most patients periodontitis is successfully treated by scaling and root planing, but some studies have shown that certain sites continue to show periodontal tissue destruction despite conventional periodontal therapy. To solve this problem, antibiotics may be administered as an adjuvant treatment. This includes azithromycin (AZM), which is effective against Gram-negative aerobic and anaerobic bacteria and has a long half-life in periodontal tissues. The purpose of the present study was to determine the efficacy of azithromycin as an adjuvant treatment for periodontitis through a review of the literature in Medline, Lilacs and Scielo, combining the keywords "azithromycin", "periodontal treatment" and "periodontitis" in both Portuguese and English languages. To be included, articles had to be clinical trials, randomized, controlled, double-blind or blind, and published between 2001 and 2011. 70 articles were found, of which 12 were selected based on title and abstract. Most studies used AZM as an adjuvant treatment for chronic periodontitis, usually in a single daily dose of $500 \mathrm{mg}$ over three days, and indicated that AZM significantly reduced probing depth and increased periodontal attachment when compared to controls. Furthermore, a reduction in red and orange complex and an increase in bacteria associated with healthy periodontal conditions were observed in subjects treated with AZM. It may be concluded that the use of AZM as an adjuvant treatment for periodontitis improves clinical and microbiological parameters when compared to conventional treatment alone.
\end{abstract}

(c) 2013 Elsevier B.V. All rights reserved.

\section{Contents}

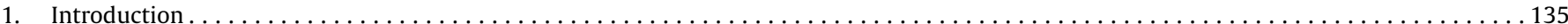

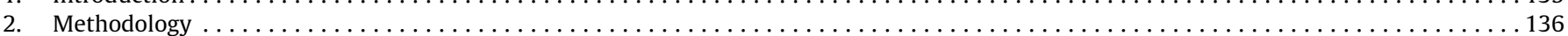

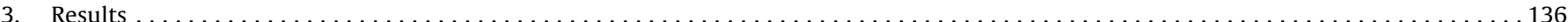

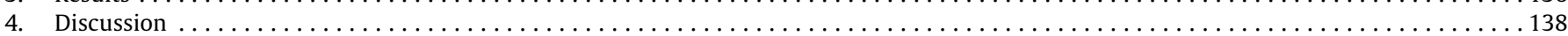

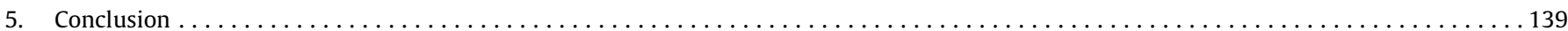

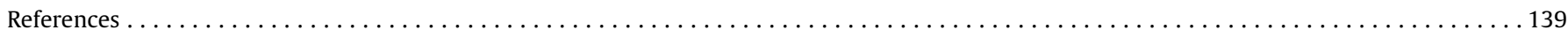

\footnotetext{
* Corresponding author. Tel.: +55858878 2003, +55853278 5983.

E-mail addresses: wilkermustafa@gmail.com (F.W.M.G. Muniz), camilacdeoliv@gmail.com (C.C. de Oliveira), roseperio@yahoo.com.br (R. de Sousa Carvalho), monicastudart@gmail.com (M.M.S.M. Moreira), betemora@matrix.com.br (M.E.A. de Moraes), rmartins@ufc.br (R.S. Martins).
}

\section{Introduction}

Periodontal diseases include a range of pathologies resulting from bacterial infection and host response (Marsh, 2006). In susceptible individuals, they are caused by specific periodontopathogens found in the supra- or subgingival biofilm (Tanner et al., 1998). Periodontitis resulting from bacterial infection can lead to loss of alveolar bone and periodontal attachment 
and, in severe cases, tooth exfoliation (Haffajee and Socransky, 1994).

Most types of periodontitis can be successfully treated by removing the supra- and subgingival biofilm by scaling and root planing combined with adequate periodontal support therapy (Ramfjord, et al., 1975). However, certain sites continue to show periodontal tissue deterioration despite conventional periodontal therapy. In addition, periodontopathogens may occasionally invade periodontal tissues and dental canaliculi from where they cannot be completely removed (Mascarenhas et al., 2005).

The use of systemic antibiotics as adjuvant treatment has been shown to be clinically more efficient than periodontal treatment associated with placebo, especially with regard to probing depth and periodontal attachment in both aggressive and chronic forms of periodontitis (Haffajee et al., 2003; Herrera et al., 2002). However, since organisms in biofilms are by far less susceptible to antimicrobials than bacteria in planktonic populations (Wilson, 1996), initial mechanical disruption of the biofilm may be required to improve the efficacy of the antibiotic therapy (Costerton et al., 1995; Müller et al., 2002).

Since most periodontopathogens are Gram-negative, a number of antibiotics specifically targeting Gram-negative bacteria have been used in periodontitis. Among the most well-known drugs are the tetracyclines and a combination of amoxicillin and metronidazole. However, despite their clinical benefits, adjuvant therapy with these drugs requires 7-14 days to be completed, at 3-4 doses per day, increasing the likelihood of noncompliance. In addition, their use has been associated with a range of side effects and with bacterial resistance (Greenberg, 1984; Yashima et al., 2009).

Azithromycin (AZM), on the other hand, is a semi-synthetic macrolide capable of inhibiting protein synthesis in the bacterial ribosome. Like erythromycin, AZM targets aerobic and anaerobic Gram-negative and Gram-positive bacteria, but is even more potent against certain Gram-negative bacteria (Retsema et al., 1987). AZM becomes highly concentrated in fibroblast and phagocytes (McDonald and Pruul, 1991). The drug is then transported along with the phagocytes which are stimulated to migrate to the site of infection due to their chemotactic activity (Schentag and Ballow, 1991).

Because the half-life of AZM is relatively long, the drug may be administered only once a day (500 mg) for 3-5 consecutive days. In addition, the adverse effects are limited (Oteo et al., 2010) and the drug is readily absorbed when taken orally. In view of these advantages, AZM is an attractive treatment option for patients with infections in which aerobic and anaerobic Gram-negative bacteria are prevalent (Retsema et al., 1987).

The purpose of the present study was to analyze the efficacy of AZM when used as adjuvant to non-surgical therapy for periodontitis, based on a review of the literature.

\section{Methodology}

To search for appropriate papers for this systematic review, three internet sources were used: MEDLINE-PubMed, LILACS and SciELO. It was combined the keywords "azithromycin", "periodontal treatment" and "periodontitis" in both Portuguese and English languages.

At first, titles and abstracts resulting from the search as described above were screened. Subsequently, full-text papers were screened and selected as the following criteria:

- Randomized Controlled Clinical Trials.

- Double-blind or blind Trials.

- In human patients.

- Intervention: use of azithromycin as an adjuvant to nonsurgical scaling and root planing.
- Control group: non-surgical scaling and root planing alone, plus placebo or plus adjuvant use of amoxicillin and/or metronidazole. - Publication date between 2001 and 2011.

Only studies written in Portuguese, English and Spanish languages were accepted. Case reports, letters and historical reviews were excluded from the search. Studies without abstracts but whose titles suggested that they could be related to the objective of this review were also selected, so the full text could be screened for eligibility.

To minimize the potential for review bias, screening was performed independently by two reviewers (F.W.M.G.M. and C.C.O.). Discrepancies with regard to the inclusion or exclusion of studies were resolved by extensively discussion between the reviewers who selected the studies. When any doubt was still remaining, another collaborator (R.S.M.) was involved in such process.

70 articles were found, of which 12 were selected.

\section{Results}

Most researchers have focused on the use of AZM in the treatment of chronic periodontitis (Gomi et al., 2007; Haffajee et al., 2007, 2008; Mascarenhas et al., 2005; Morozumi et al., 2010; Oteo et al., 2010; Plaza et al., 2003; Pradeep et al., 2008; Sampaio et al., 2011; Smith et al., 2002; Yashima et al., 2009). To the best of our knowledge, only one clinical trial has used AZM in the treatment of aggressive periodontitis (Haas et al., 2008). The main results of these studies are shown in Table 1.

Most studies evaluating clinical parameters after AZM administration adjuvant to non-surgical periodontal therapy have reported significantly reduced gingival bleeding and biofilm regardless of AZM administration, (Haas et al., 2008; Oteo et al., 2010; Pradeep et al., 2008; Sampaio et al., 2011; Smith et al., 2002) but in some studies, probing depth and periodontal attachment were found to improve significantly when AZM was used (Mascarenhas et al., 2005; Oteo et al., 2010; Smith et al., 2002; Yashima et al., 2009;). In one of this studies, 44 patients with chronic periodontitis were assigned to one of two groups: treatment with AZM or control (Smith et al., 2002). Throughout the study period (22 weeks), probing depth was significantly smaller and periodontal attachment was significantly greater in the treatment group. Similar results were reported in another study in which patients with chronic periodontitis were submitted to adjuvant treatment with AZM and followed over 12 months (Haffajee et al., 2007).

In the study above, (Smith et al., 2002) at baseline pockets measured $6.72 \mathrm{~mm}$ on the average. After 22 weeks, the average probing depth had decreased to $3.67 \mathrm{~mm}$ in the AZM treatment group versus $4.54 \mathrm{~mm}$ in the control groupa statistically significant difference. This is supported by another clinical study (Mascarenhas et al., 2005) in which drug therapy led to a $3.52 \mathrm{~mm}$ reduction in probing depth, compared to only $1.98 \mathrm{~mm}$ in the control group.

AZM was administered for 3 consecutive days ( $500 \mathrm{mg} / \mathrm{day}$ ) in a study involving 24 patients diagnosed with aggressive periodontitis (Haas et al., 2008). Although improvement was similar in the treatment group (AZM) and the control group (placebo) after three months, at 6 and 12 months periodontal attachment continued to improve in patients receiving AZM but stabilized in patients receiving placebo. Patients in the treatment group displayed a greater percentage of teeth with more than 1 or $2 \mathrm{~mm}$ reduction in probing depth when compared to the control group. However, improvement was similar in the two groups with regard to bleeding on probing. 


\begin{tabular}{|c|c|c|c|c|c|}
\hline Reference & $\begin{array}{l}\text { Number of } \\
\text { patients }\end{array}$ & $\begin{array}{l}\text { Type of } \\
\text { periodontitis }\end{array}$ & $\begin{array}{l}\text { Dosage of } \\
\text { azithromycin }\end{array}$ & Main results & $P$-value \\
\hline $\begin{array}{l}\text { Smith et al., } \\
2002\end{array}$ & 46 & Chronic & $\begin{array}{l}500 \mathrm{mg} \text { (single dose) } \\
\text { for } 3 \text { days }\end{array}$ & $\begin{array}{l}\text { After } 22 \text { weeks, PD of the moderate pockets was reduced from a mean of } 4.58 \mathrm{~mm} \text { at baseline for both groups to } 2.79 \mathrm{~mm} \text { and } 3.31 \mathrm{~mm} \text { in } \\
\text { AZM group and placebo group, respectively, showing a statistically significant difference between groups } \\
\text { After } 22 \text { weeks, PD of the deep pockets was reduced from a mean of } 6.76 \mathrm{~mm} \text { at baseline for both groups to } 3.67 \mathrm{~mm} \text { and } 4.54 \mathrm{~mm} \text { in AZM } \\
\text { group and placebo group, respectively, showing a statistically significant difference between groups }\end{array}$ & $P<0.01$ \\
\hline $\begin{array}{l}\text { Plaza } \\
\text { et al.,2003 }\end{array}$ & 19 & Chronic & $\begin{array}{l}500 \mathrm{mg} \text { (single dose) } \\
\text { for } 3 \text { days }\end{array}$ & $\begin{array}{l}\text { The average PD at baseline was } 9.25 \pm 0.52 \mathrm{~mm} \text { and } 9.27 \pm 0.30 \mathrm{~mm} \text { for control and test group, respectively. At the end of the study, these } \\
\text { values were } 8.92 \pm 0.52 \mathrm{~mm} \text { and } 8.01 \pm 2.41 \mathrm{~mm} \text {, showing a statistically significant difference between groups }\end{array}$ & $P<0.01$ \\
\hline $\begin{array}{r}\text { Mascarenhas } \\
\text { et al., } 2005\end{array}$ & 31 & Chronic & $\begin{array}{l}500 \mathrm{mg}(1 \text { st day) } \\
+250 \mathrm{mg}(2 \mathrm{nd}-5 \text { th day })\end{array}$ & $\begin{array}{l}\text { PD was reduced at } 0.45 \text { and } 1.33 \mathrm{~mm} \text { in control and test group, respectively, showing a statistically significant difference between groups } \\
\text { CAL gain of } 0.46 \text { and } 1.13 \mathrm{~mm} \text { in control and test group, respectively, showing a statistically significant difference between groups }\end{array}$ & $P<0.05$ \\
\hline Gomiet al.,2007 & 34 & Chronic & $\begin{array}{l}500 \mathrm{mg} \text { (single dose) } \\
\text { for } 3 \text { days }\end{array}$ & $\begin{array}{l}\text { The average PD at baseline was } 4.05 \pm 0.68 \mathrm{~mm} \text { and } 3.98 \pm 1.06 \mathrm{~mm} \text { for control and test group, respectively. At the end of the study, these } \\
\text { values were } 3.30 \pm 0.36 \mathrm{~mm} \text { and } 2.36 \pm 0.76 \mathrm{~mm} \text {, showing a statistically significant difference between groups } \\
\text { The BOP rates at baseline were } 31.43 \pm 18.46 \% \text { and } 31.42 \pm 17.15 \% \text { for control and test group, respectively. At the end of the study, these } \\
\text { rates were } 12.91 \pm 7.62 \% \text { and } 5.35 \pm 2.91 \% \text {, showing a statistically significant difference between groups }\end{array}$ & $P<0.001$ \\
\hline $\begin{array}{l}\text { Haffajee et al., } \\
2007\end{array}$ & 92 & Chronic & $\begin{array}{l}500 \mathrm{mg} \text { ( single dose) } \\
\text { for } 3 \text { days }\end{array}$ & $\begin{array}{l}\text { Subjects receiving AZM as an adjuvant to SRP exhibited greater clinical improvement than subjects receiving SRP only for PD } \\
\text { Subjects receiving AZM as an adjuvant to SRP exhibited greater clinical improvement than subjects receiving SRP only for CAL }\end{array}$ & $\begin{array}{l}P<0.001 \\
P<0.05\end{array}$ \\
\hline $\begin{array}{l}\text { Haas et al., } \\
2008\end{array}$ & 24 & Aggressive & $\begin{array}{l}500 \mathrm{mg} \text { ( single dose) } \\
\text { for } 3 \text { days }\end{array}$ & $\begin{array}{l}\text { PD was reduced } 1.85 \mathrm{~mm} \text { and } 2.88 \mathrm{~mm} \text { in control and test group, respectively, showing a statistically significant difference } \\
\text { The percentage of CAL gain, at the end of the study, was } 63.63 \text { and } 81.34 \text { for control group and test group, showing a statistically } \\
\text { significant difference }\end{array}$ & $\begin{array}{l}P=0.025 \\
P=0.037\end{array}$ \\
\hline $\begin{array}{l}\text { Haffajee et al., } \\
2008\end{array}$ & 92 & Chronic & $\begin{array}{l}500 \mathrm{mg} \text { (single dose) } \\
\text { for } 3 \text { days }\end{array}$ & $\begin{array}{l}\text { Compared to those who received SRP alone, subjects receiving systemically administered azithromycin demonstrated significant } \\
\text { reductions in red and many orange complex species at } 2 \text { weeks }\end{array}$ & $\begin{array}{l}P<0.05 \\
P<0.01 \\
P<0.001\end{array}$ \\
\hline $\begin{array}{l}\text { Pradeep et al., } \\
2008\end{array}$ & 80 & Chronic & $\begin{array}{l}\text { Single irrigation with } \\
0.5 \% \text { gel }\end{array}$ & $\begin{array}{l}\text { PD was reduced in } 2.13 \pm 0.35 \mathrm{~mm} \text { and } 2.53 \pm 0.52 \mathrm{~mm} \text { in control and test group, respectively, showing a statistically significant } \\
\text { difference between groups } \\
\text { CAL gain was } 0.60 \pm 0.63 \mathrm{~mm} \text { and } 1.07 \pm 0.70 \mathrm{~mm} \text { in control and test group, respectively, showing a statistically significant difference } \\
\text { between groups }\end{array}$ & $P<0.05$ \\
\hline $\begin{array}{l}\text { Yashima et al., } \\
2009\end{array}$ & 30 & Chronic & $\begin{array}{l}500 \mathrm{mg} \text { ( single dose) } \\
\text { for } 3 \text { days }\end{array}$ & $\begin{array}{l}\text { A statistically significant difference was observed between tests groups and control group for PD } \\
\text { A statistically significant difference was observed between tests groups and control group for CAL } \\
\text { A statistically significant difference was observed between tests groups and control group for BOP at any time point }\end{array}$ & $\begin{array}{l}P<0.01 \\
P<0.05 \\
P<0.01\end{array}$ \\
\hline $\begin{array}{l}\text { Morozumi } \\
\text { et al., } 2010\end{array}$ & 30 & Chronic & $\begin{array}{l}500 \mathrm{mg} \text { (single dose) } \\
\text { for } 3 \text { days }\end{array}$ & After SRP, bacteremia frequency was $90 \%$ for control group, and $20 \%$ for AZM group & $P=0.008$ \\
\hline $\begin{array}{l}\text { Oteo et al., } \\
2010\end{array}$ & 29 & Chronic & $\begin{array}{l}500 \mathrm{mg} \text { (single dose) } \\
\text { for } 3 \text { days }\end{array}$ & $\begin{array}{l}\text { PD was reduced in } 0.38 \text { and } 0.78 \mathrm{~mm} \text { in control and test group, respectively, showing a statistically significant difference between groups } \\
\text { A significant gain in mean CAL was observed. However, changes in the placebo group were not significant }\end{array}$ & $\begin{array}{l}P=0.009 \\
P=0.004\end{array}$ \\
\hline $\begin{array}{l}\text { Sampaio et al., } \\
2011\end{array}$ & 40 & Chronic & $\begin{array}{l}500 \mathrm{mg} \text { (single dose) } \\
\text { for } 5 \text { days }\end{array}$ & $\begin{array}{l}\text { The average PD at baseline was } 5.02 \pm 0.66 \mathrm{~mm} \text { and } 4.82 \pm 0.84 \mathrm{~mm} \text { for control and test group, respectively. At the end of the study, these } \\
\text { values were } 3.34 \pm 0.50 \mathrm{~mm} \text { and } 3.36 \pm 0.44 \mathrm{~mm} \text {, not showing any statistically significant difference between groups } \\
\text { The average CAL at baseline was } 5.74 \pm 0.83 \mathrm{~mm} \text { and } 5.51 \pm 0.94 \mathrm{~mm} \text { for control and test group, respectively. At the end of the study, these } \\
\text { values were } 4.69 \pm 0.89 \mathrm{~mm} \text { and } 4.44 \pm 0.77 \mathrm{~mm} \text {, not showing any statistically significant difference between groups }\end{array}$ & $P>0.05$ \\
\hline
\end{tabular}


Only one of the studies reviewed found no additional clinical benefits of AZM as adjuvant to conventional periodontal therapy. The study evaluated the clinical and microbiological parameters of 40 patients with chronic periodontitis (Sampaio et al., 2011). Compared to baseline values, improvement was similar for the treatment group and the control group with regard to clinical parameters. Thus, the results of the study suggest adjuvant AZM therapy has no additional clinical benefit in chronic periodontitis, compared to conventional mechanical periodontal treatment.

Only one clinical trial used AZM in a topical administration (0.5\%) (Pradeep et al., 2008). It was noticed a reduction in probing depth and improved periodontal attachment compared to controls. The authors hypothesized that the application of AZM at the site of inflammation facilitated the penetration of the drug into the periodontal tissues, resulting in a high drug concentration in the periodontal pockets and enhancing the bactericidal effect. The double effect of the drug on the local microflora and on the invading pathogens may result in clinical improvement without systemic side effects or the development of bacterial resistance.

In a microbiological investigation of patients with chronic periodontitis submitted to chemical-mechanical treatment with AZM, (Haffajee et al., 2008) considerable reductions in red-complex bacteria and some species of orange-complex bacteria were observed after two weeks of therapy.

However, another study (Sampaio et al., 2011) found that red and orange complex bacteria were reduced at 6 and 12 month in both control and test groups, showing no additional clinical benefit in chronic periodontitis, compared to conventional mechanical periodontal treatment.

Two clinical studies found the clinical procedures of scaling and root planing to be associated with high levels of bacteremia (Gomi et al., 2007; Morozumi et al., 2010). However, when prophylaxis with AZM was started three days prior to mechanical periodontal therapy, bacteremia occurred significantly less frequently, compared to the control group.

AZM is generally well tolerated, but side effects may occur. In one study, a patient presented an allergic reaction while another reported having problems swallowing the pills, though completing the treatment protocol (Haffajee et al., 2007). Only one patient reported gastrointestinal effects from the use of AZM (Plaza et al., 2003).

\section{Discussion}

Studies evaluating AZM as adjuvant to non-surgical treatment for periodontitis have used different methodologies. The fact that only one study used the drug as adjuvant in patients with aggressive periodontitis (Haas et al., 2008) is evidence of a lack of information in the literature regarding this type of treatment.

Because AZM has a long half-life, most studies have employed a protocol of $500 \mathrm{mg}$ /day for three days (Gomi et al., 2007; Haas et al., 2008; Haffajee et al., 2007, 2008; Morozumi et al., 2010; Oteo et al., 2010; Plaza et al., 2003; Smith et al., 2002; Yashima et al., 2009). Exceptions to this rule is a study administering a single dose of $500 \mathrm{mg}$ for five days (Sampaio et al., 2011), a study in which patients received $500 \mathrm{mg}$ on the first day and $250 \mathrm{mg}$ /day on the following four days (Mascarenhas et al., 2005), and a clinical trial that used a single irrigation with $0.5 \%$ gel of AZM (Pradeep et al., 2008).

The similar findings of plaque index and marginal bleeding for patients receiving AZM and placebo may be explained by the use of mechanical control of the supragingival biofilma procedure essential to biofilm reduction and, consequently, to the control of gingival inflammation. Since all the patients in the reviewed studies also received instructions in oral hygiene, the observed lower indices are not surprising, even in patients receiving no antibiotics.

Overall, compared to patients with shallow and moderately deep periodontal pockets, in patients with deep pockets at baseline, improvement tends to be greater when antibiotics are administered (Haffajee et al., 2007; Mascarenhas et al., 2005; Oteo et al., 2010; Smith et al., 2002). This is an expected finding since mechanical therapy is less efficient in deep pockets, making drug therapy particularly beneficial. However, despite the observed improvement, these deep pockets continue to have the greatest probing depth in the mouth throughout the period of periodontal maintenance.

Previously, it was proved that AZM can act against some periodontopathogens, having a moderate susceptibility of Actinobacillus actinomycetemcomitans strains (Müller et al., 2002). To inhibit $90 \%$ of $A$. actinomycetemcomitans strains were necessary a concentration of $3 \mu \mathrm{g} / \mathrm{mL}$ of azithromycin, while doxycycline needed a $1 \mu \mathrm{g} / \mathrm{mL}$ and metronidazole a $>256 \mu \mathrm{g} / \mathrm{mL}$ concentration, showing a good susceptibility to doxycycline and a resistance to metronidazole to that strains.

Based on this fact, the microbiological aspects of the teeth are also dramatically affected by periodontal therapy: the removal of the biofilm significantly reduces the total number of periodontopathogens, especially when AZM is administered (Haffajee et al., 2008; Oteo et al., 2010; Pradeep et al., 2008). Or, more precisely, red and orange-complex bacteria are reduced, and bacteria associated with periodontal health are increased (Haffajee et al., 2008). Concurrently, clinical parameters improve, possibly because of the significant reduction in the number of periodontopathogens, especially in the first two weeks following scaling and root planing (Haffajee et al., 2008; Oteo et al., 2010). This helps sustain improvements in clinical parameters even beyond 12 months of follow-up.

Nowadays, appearance of bacterial strains resistant to antibiotics is in evidence since this can cause complication in patient treatment. One study analysed the percentage of resistant species to AZM after periodontal treatment (Haffajee et al., 2008). It was noticed that antibiotic resistance increase significantly two weeks after AZM administration, and this remain until six months, but after 12 months the percentage of resistant species were reduced to levels approached those detected before periodontal therapy.

In addition, it is suggested that AZM produces anti-inflamatory effects in gingiva, decreasing levels of IL-1 $\beta$, IL- 8 and TNF- $\alpha$ recovered from pooled gingival crevicular fluid (GCF) samples (Ho et al., 2010). Furthermore, it is related a significant decrease GCF volume after 2, 4, and 7 days first dose AZM administration (Ho et al., 2010). The relationship noticed between these two facts, decrease in GCF flow rate and GCF pro-inflammatory cytokine, suggests that AZM's effects on GCF volume could be mediated by inhibiting the production of one or more of these biological mediators. Although it was proved a possible AZM antiinflammatory effect, this study has some limitations, such as a small number of volunteers.

In addition to being effective as adjuvant therapy in periodontitis, as shown in several studies, AZM has advantages over other antibiotics used in this patient population: (i) the simplicity of the treatment protocol, requiring a single daily dose of $500 \mathrm{mg}$ for 3-5 consecutive days, improves adherence, (ii) high drug concentrations can be maintained in affected tissues as AZM is transported by phagocytes, (Smith et al., 2002) (iii) the incidence of side effects is low, (Oteo et al., 2010) (iv) the rapid reduction in the bacterial load of infected sites favors healing, (Mascarenhas et al., 2005) and (v) bacteremia is reduced when the drug is used preventively, (Gomi et al., 2007; Morozumi et al., 2010) making AZM a safe treatment option when antibiotic prophylaxis is desired. 
Under these circumstances, periodontal treatment combined with AZM administration can reach much better clinical outcomes than conventional periodontal treatment alone.

\section{Conclusion}

Based on our literature review, the use of azithromycin as adjuvant to conventional treatment for chronic and aggressive periodontitis generally improves clinical and microbiological findings compared to conventional treatment alone. AZM has several advantages over other antibiotics, especially with regard to treatment protocol and adherence. Nevertheless, AZM therapy should be prescribed and managed with clearly defined criteria to prevent the emergence of bacterial resistance, though the risk is known to be relatively small.

\section{References}

Costerton, J.W., Lewandowski, Z., Caldwell, D.E., Korber, D.R., Lappin-Scott, H.M., 1995. Microbial biofilms. Annu. Rev. Microbiol. 49, 711-745.

Gomi, K., Yashima, A., Nagano, T., Kanazashi, M., Maeda, N., Arai, T., 2007. Effects of full-mouth scaling and root planing in conjunction with systemically administered azithromycin. J. Periodontol. 78, 422-429.

Greenberg, R.N., 1984. Overview of patient compliance with medication dosing: a literature review. Clin. Ther. 6, 592-599.

Haas, A.N., Castro, G.D., Moreno, T., Susin, C., Albandar, J.M., Oppermann, R.V., Rösing, C.K., 2008. Azithromycin as an adjunctive treatment of aggressive periodontitis: 12-months randomized clinical trial. J. Clin. Periodontol. 35, 696-704.

Haffajee, A.D., Patel, M., Socransky, S.S., 2008. Microbiological changes associated with four different periodontal therapies for the treatment of chronic periodontitis. Oral Microbiol. Immunol. 23, 148-157.

Haffajee, A.D., Socransky, S.S., 1994. Microbial etiological agents of destructive periodontal disease. Periodontol. 2000, 78-1115, 78-111.

Haffajee, A.D., Socransky, S.S., Gunsolley, J.C., 2003. Systemic anti-infective periodontal therapy. A systematic review. Ann. Periodontol. 8, 115-181.

Haffajee, A.D., Torresyap, G., Socransky, S.S., 2007. Clinical changes following four different periodontal therapies for the treatment of chronic periodontitis: 1year results. J. Clin. Periodontol. 34, 243-253.

Herrera, D., Sanz, M., Jepsen, S., Needleman, I., Roldan, S., 2002. A systematic review on the effect of systemic antimicrobials as an adjunct to scaling and root planing in periodontitis patients. J. Clin. Periodontol. 29 (Suppl), 136-159.

Ho, W., Eubank, T., Leblebicioglu, B., Marsh, C., Walters, J., 2010. Azythomycin decreases crevicular fluid volume and mediator content. J. Dent. Res. 89, 831-835.
Marsh, P.D., 2006. Dental plaque as a biofilm and a microbial communityimplications for health and disease. BMC Oral Health. 6 (suppl), 1-7.

Mascarenhas, P., Gapski, R., Al-Shammari, K., Hill, R., Soehren, S., Fenno, J.C., Giannobile, W.V., Wang, H.L., 2005. Clinical response of Azithromycin as an adjunct to non-surgical periodontal therapy in smokers. J. Periodontol. 76, 426-436.

McDonald, R.J., Pruul, H., 1991. Phagocytic uptake and transport of azithromycin. Eur. J. Clin. Microbiol. Infect. Dis. 10, 828-833.

Morozumi, T., Kubota, T., Abe, D., Shimizu, T., Komatsu, Y., Yoshie, H., 2010. Effects of irrigation with an antiseptic and oral administration of azithromycin on bacteremia caused by scaling and root planing. J. Periodontol. 81, 1555-1563.

Müller, H.P., Holderrieth, S., Burkhardt, U., Höffler, U., 2002. In vitro antimicrobial susceptibility of oral strains of Actinobacillus actinomycetemcomitans to seven antibiotics. J. Clin. Periodontol. 29, 736-742.

Oteo, A., Herrera, D., Figuero, E., O'Connor, A., Gonzáles, I., Sanz, M., 2010. Azithromycin as an adjunct to scaling and root planing in the treatment of Porphyromonas gingivalis-associated periodontitis: a pilot study. J. Clin. Periodontol. 37, 1005-1015.

Plaza, J.C., Gallardo, F., Davila, L., Rioseco, M., 2003. Efectos de uma terapia sistémica con azitromicina em el tratamento de la periodontites crónica. Av. Periodon. Implantol. 16, 35-42.

Pradeep, A.R., Sagar, S.V., Daisy, H., 2008. Clinical and microbiologic effects of subgingivally delivered $0.5 \%$ azithromycin in the treatment of chronic periodontitis. J. Periodontol. 79, 2125-2135.

Ramfjord, S.P., Knowles, J.W., Nissle, R.R., Burgett, F.G., Shick, R.A., 1975. Results following three modality of periodontal therapy. J. Periodontol. 46, 522-526.

Retsema, J., Girard, A., Schelkly, W., Manousos, M., Anderson, M., Bright, G., Borovoy, R., Brennan, L., Mason, R., 1987. Spectrum and mode of action of azithromycin (CP-62,993), a new 15-membered-ring macrolide with improved potency against gram-negative organisms. Antimicrob. Agents. Chemother. 31, 1939-1947.

Sampaio, E., Rocha, M., Figueiredo, L.C., Faveri, M., Duarte, P.M., Lira, E.A.G., Feres, M., 2011. Clinical and microbiological effects of azithromycin in the treatment of generalized chronic periodontitis: a randomized placebo-controlled clinical trial. J. Clin. Periodontol. 38, 838-846.

Schentag, J.J., Ballow, C.H., 1991. Tissue-directed pharmacokinetics. Am. J. Med. 91, $5 \mathrm{~S}-11 \mathrm{~S}$.

Smith, S.R., Foyle, D.M., Daniels, J., Joyston-Bechal, S., Smales, F.C., Sefton, A., Williams, J., 2002. A double-blind placebo-controlled trial of azithromycin as an adjunct to non-surgical treatment of periodontitis in adults: clinical results. J. Clin. Periodontol. 29, 54-61.

Tanner, A., Maiden, M.F.J., Machuch, P., Murray, L.L., Kent Jr., R.L., 1998. Microbiota of health, gingivitis and initial periodontitis. J. Clin. Periodontol. 25, 85-89.

Wilson, M., 1996. Susceptibility of oral bacterial biofilms to antimicrobial agents J. Med. Microbiol. 44, 79-87.

Yashima, A., Gomi, K., Maeda, N., Arai, T., 2009. One-stage full-mouth versus partial-mouth scaling and root planing during the effective half-life of systemically administered Azithromycin. J. Periodontol. 80, 1406-1413. 